\title{
WITHDRAWN: Implementasi Strategi Pemasaran dalam Meningkatkan Potensi Makanan Tradisional
}

Simanihuruk, M. (2018). Implementasi Strategi Pemasaran dalam Meningkatkan Potensi Makanan Tradisional. Barista: Jurnal Kajian Bahasa dan Pariwisata, 5(2), 222-234.

Article withdrawn by publisher.

This article was accidentally published twice in the online version of Volume 5 Issue 1 and Volume 5 Issue 2, with different DOIs.

The incorrect version of the article with DOI: 10.34013/barista.v5i2.124 has been replaced with this correction notice.

The correct and citable version of the article remains:

Simanihuruk, M. (2018). IMPLEMENTASI STRATEGI PEMASARAN DALAM MENINGKATKAN POTENSI MAKANAN TRADISIONAL DI DESA SAKERTA TIMUR, CIREBON. Barista: Jurnal Kajian Bahasa dan Pariwisata, 5(1), 59-71. 